\title{
Wollastonite-scapolite-clinopyroxene marble of the Anápolis-Itauçu Complex, Goiás: more evidence of ultrahigh-temperature metamorphism
}

\author{
Renato Moraes ${ }^{1}$, Reinhardt Adolfo Fuck', Michael Brown ${ }^{3}$, Philip Piccoli', \\ Julia Baldwin ${ }^{4}$, Elton Luis Dantas', Jorge Henrique Laux ${ }^{2} \&$ Sérgio Luiz, Junges ${ }^{2}$
}

\begin{abstract}
Impure marble in a quarry near Goianira in the Anápolis-Itauçu Complex, central Brazil, contains blocks of contrasting calc-silicate rocks with different bulk compositions, producing a range of mineral assemblages during granulite facies metamorphism. The subject of this paper is the common host impure marble from the quarry outcrop, which is composed of calcite, clinopyroxene, quartz, ternary feldspar, titanite, wollastonite and scapolite. Wollastonite and scapolite only occur together in layers of appropriate bulk composition, and the coexistence of these minerals is diagnostic of ultrahigh-temperature (UHT) metamorphism $\left(T>900^{\circ} \mathrm{C}\right.$ ). In thin section, although rare, wollastonite and scapolite are observed in mutual contact. More commonly, wollastonite exhibits a corona of calcite+quartz, but where wollastonite is close to scapolite, these minerals are separated by a corona of grossular with plagioclase+calcite+quartz. The coexistence of wollastonite+scapolite in contact is inferred to record the metamorphic peak and the coronae are interpreted as an early post-peak retrograde feature. Another indication of UHT metamorphism is the presence of ternary feldspar, in which exsolved andesine occurs in an orthoclase host. Titanite yields a TIMS U-Pb age of $632 \pm 6 \mathrm{Ma}$, which we interpret as a post-peak cooling age during regional UHT metamorphism. Zircon from intrusive rocks nearby the marble yields a SIMS $\mathrm{U}-\mathrm{Pb}$ age of $626 \pm 2 \mathrm{Ma}$. Since these two ages overlap within uncertainty, we cannot rule out the possibility that contact metamorphism was the heat source for UHT metamorphism.
\end{abstract}

Keywords: Anápolis-Itauçu Complex, Brasília Fold Belt, calc-silicate rock, ultrahigh temperature metamorphism, wollastonite+scapolite.

Resumo Wollastonita-escapolita-clinopiroxênio mármore do Complexo Anápolis-Itauçu, Goiás: evidência adicional de metamorfismo de temperatura ultra-alta. Em pedreira próxima a Goianira, Goiás, ocorrem mármore impuro e rochas calcissilicáticas com grande variedade de associações metamórficas. O objetivo principal do presente trabalho é o mármore impuro da pedreira, composto por calcita, clinopiroxênio, escapolita, wollastonita, titanita, feldspato ternário, quartzo e ilmenita. Wollastonita e escapolita ocorrem em porções de composição adequada e a ocorrência dos dois minerais em contato é diagnóstica de condições de metamorfismo de temperatura ultra-alta $\left(T>900^{\circ} \mathrm{C}\right)$. Em lâmina petrográfica, raramente a coexistência de wollastonita e escapolita é observada. Normalmente wollastonita apresenta coroa de calcita+quartzo e quando está próxima à escapolita, são separadas por coroa complexa de grossulária com quartzo, plagioclásio e calcita. A coexistência de wollastonita e escapolita ocorreu durante o auge do metamorfismo e as coroas de reação foram originadas durante o resfriamento após o pico metamórfico. Outra evidência de metamorfismo de temperatura ultra-alta é a presença de feldspato ternário, em que exsoluções de andesina ocorrem em ortoclásio. Idade ID-TIMS U-Pb em titanita é de $632 \pm 6 \mathrm{Ma}$, interpretada como idade de resfriamento após o pico do metamorfismo de temperatura ultra-alta. Idade de grãos de zircão de intrusivas máficas das proximidades de Goianira é $626 \pm 2$ Ma. Como existe sobreposição dessas idades, considerando as incertezas, não é possível descartar que o metamorfismo de temperatura ultra-alta tenha como fonte o calor do magma intrusivo.

Palavras-chave: Complexo Anápolis-Itauçu, Faixa Brasília, metamorfismo de temperatura ultra-alta, rocha calciossilicática, wollastonita+escapolita.

INTRODUCTION Ultrahigh temperature (UHT) refers to crustal metamorphism where temperatures exceed $900^{\circ} \mathrm{C}$ (Harley 1998). Such extreme granulites were previously described in Brazil in rocks from the Itabuna-Salvador-Curaçá Belt in Bahia (Stormer Jr.
1973, Leite 2002), and the Niquelândia Complex (Ferreira Filho et al. 1998), Barro Alto Complex (Moraes \& Fuck 2000) and Anápolis-Itauçu Complex (Moraes et al. 2002, Baldwin et al. 2005) in Goiás. In Brazil, UHT granulites occur as isolated outcrops within 'common'

1 - IGc, Universidade de São Paulo, São Paulo (SP) Brasil. E-mail: moraes@igc.usp.br

2 - IG, Universidade de Brasília, Brasília (DF), Brasil. reinhardt@unb.br, elton@unb.br, lauxjh@unb.br, sjunges@yahoo.com

3 - Laboratory for Crustal Petrology, Department of Geology, University of Maryland, USA. E-mail: mbrown@geol.umd.edu, piccoli@geol.umd.edu

4 - Department of Geology, University of Montana, Missoula, USA. E-mail: julie.baldwin@umontana.edu 
granulites, in similar fashion to those described from Antarctica (Harley \& Hensen 1990) and India (Brown \& Raith 1996). Most commonly, UHT granulites are recognized by the diagnostic mineral assemblages that occur in pelites, which are sapphirine+quartz, aluminous orthopyroxene+sillimanite+quartz, hercynite-rich spinel+quartz, and osumilite+garnet (Harley 1998). However, calc-silicate rocks also may contain diagnostic UHT mineral assemblages, e.g. where wollastonite and scapolite occur together as a stable mineral assemblage. In Brazil, wollastonite+scapolite were previously described in marbles from Caconde, Minas Gerais (Oliveira \& Alves 1976). Here we describe the first occurrence from the Anápolis-Itauçu Complex of wollastonite in stable coexistence with scapolite in impure marble.

THE ANÁPOLIS-ITAUÇU COMPLEX The Brasília Fold Belt borders the western margin of the São Francisco craton. The two tectonic divisions of the belt are as follows (Fuck et al. 1994): an eastern, external zone comprising sedimentary and metasedimentary cratonic cover sequences that are progressively more deformed and metamorphosed to the west; and, a western, inner zone that is composed of the Araxá Group, the Anápolis-Itauçu Complex, the Goiás Massif, and the Goiás Magmatic Arc. The Araxá Group comprises turbidite-type sediments, volcanic rocks, ophiolitic mélange and granite intrusions, with metamorphism ranging from greenschist to amphibolite facies conditions, whereas the Anápolis-Itauçu Complex comprises granulites, volcano-sedimentary sequences and intrusive granites. The Goiás Magmatic Arc consists of Neoproterozoic juvenile arc rocks, comprising volcano-sedimentary rocks, and tonalite and granodiorite gneisses; arc magmatism extended between 900 and $800 \mathrm{Ma}$, and pre-collisional calc-alkaline magmatism lasted until ca. $640 \mathrm{Ma}$ (Pimentel et al. 2000). The Goiás Massif comprises Archean granitegreenstone terrains, Paleoproterozoic orthogneiss, and folded Proterozoic cover rocks (Pimentel et al. 2000, 2004).

The Anápolis-Itauçu Complex (AIC) occupies a NNW-oriented area $(260 \mathrm{~km} \times 70 \mathrm{~km})$ and is bounded on both sides by mylonite zones separating the complex from the Araxá Group on the east, and from the Goiás Magmatic Arc on the west. The AIC comprises an orthogneiss unit derived from tonalite, granodiorite, and mafic-ultramafic layered bodies; a paragneiss unit, including aluminous granulite, garnet-sillimanite gneiss, calc-silicate rocks, marble, and quartzite; other rocks include volcano-sedimentary sequences and a large number of elongate, NW-SE-oriented granite intrusions (Lacerda Filho et al. 1991). Recent geochronological data from the AIC indicate that magmatism and metamorphism occurred $c a$. 650-620 Ma, related to final ocean closure between the São Francisco, Paranapanema and Amazonian cratons (Piuzana et al. 2003, Pimentel et al. 2004, Laux et al. 2004).

UHT granulites in the AIC have been iden- tified at three localities (Moraes et al. 2002). North of Goiânia (ML-67), an impure quartzite preserves aluminous orhopyroxene+sillimanite + quartz and sapphirine +quartz assemblages; reaction microstructures and high $\mathrm{Al}_{2} \mathrm{O}_{3}$ in orthopyroxene (12.9 wt. \%) allowed the inference of a composite $P-T$ path, with discrete decompression followed by a near-isobaric cooling stage from $T>1,000^{\circ} \mathrm{C}$ at $>9 \mathrm{kbar}$ to $<900^{\circ} \mathrm{C}$ (Moraes et al. 2002, Baldwin et al. 2005). Near Damolândia (PT-62) and in the Monjolo stream (ANA-287), sapphirine occurs in both quartz-rich and quartz-poor rocks. In both rocks a succession of complex reaction microstructures of symplectites and coronae allows inference of a composite $P-T$ path, involving a decompression segment to $<8 \mathrm{kbar}$ at $>1,000^{\circ} \mathrm{C}$, followed by a near-isobaric cooling to $<600^{\circ} \mathrm{C}$ at $<6 \mathrm{kbar}$ (Moraes et al. 2002). UHT granulites were known only locally within Anápolis-Itauçu Complex (Moraes et al. 2002), but recently several new occurrences of spinel+quartz, which also may be diagnostic of UHT metamorphism, were discovered between Itauçu and Petrolina de Goiás (Moraes et al. 2006), and now the main subject of this paper is another new occurrence. The calc-silicate rocks described here are located $3 \mathrm{~km}$ from Goianira (Fig. 1); they are well exposed in a quarry and form a lens within 'common' granulites. The contact relationship between the calc-silicate lens and surrounding granulites is poorly constrained. It is also not known if the GoianiraTrindade mafic-layered intrusion (Nilson 1984), that is intrusive in the country granulites, is in contact with the calc-silicate rocks or not. Our future work is going to concentrate on mapping the calc-silicate lens and host granulites.

\section{WOLLASTONITE-SCAPOLITE CALC-SIL- ICATE ROCKS FROM ANÁPOLIS-ITAUÇU} COMPLEX The main rock is a white, mediumgrained, foliated impure marble, which includes lenses and nodules of calc-silicate rock with different bulk compositions, with sharp contacts. All rocks have calcite, clinopyroxene, ternary feldspar (orthoclase with plagioclase exsolution, Fig. 2a), titanite, quartz, and wollastonite or scapolite; plagioclase is rare and may occur as anti-perthite or in coronae, as described below. Most rocks have a granoblastic fabric with silicates surrounded by calcite. Wollastonite may have a thin corona of calcite+quartz (Fig. 2b). Although rare, wollastonite and scapolite are observed in direct contact in some thin sections (Fig. 2c), but more commonly they are separated by a complex granular intergrowth of grossular-rich garnet+quartz+plagioclase \pm calcite (Fig. 2d, e). Some scapolite grains are replaced by plagioclase + calcite. Titanite forms sub-idioblastic grains (Fig. 2c), rarely presents ilmenite at its rims and occurs widespread, and in contact with all other phases. These microstructures indicate that the rocks may have crossed one or more of the following reactions during cooling and/or decompression and cooling, according to the different equilibration volumes (abbreviations after Kretz 1983): 


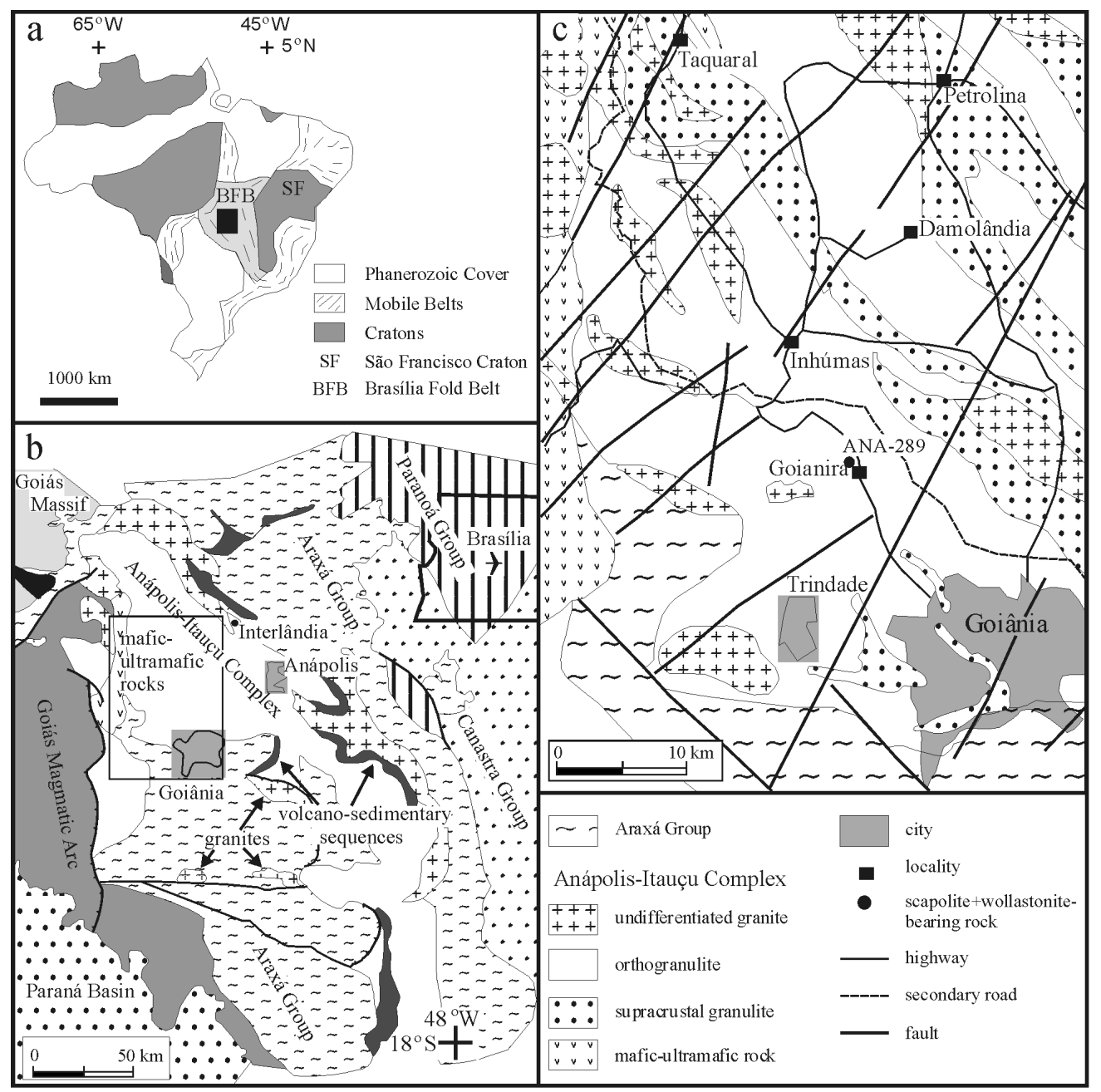

Figure 1 - (a) Map of Brazil with location of main tectonic units and study area. (b) Sketch geological map of the southern portion of the Brasilia Fold Belt with distribution of the Anápolis-Itauçu Complex and the surrounding units (after Laceda Filho et al. 1991 and Pimentel et al. 2000). Box marks the area shown in more detail in (c). (c) Geological map of the Anápolis-Itauçu Complex in the neighbourhood of Goiannia and Goianira, with the locality discussed in this study.

$$
\begin{aligned}
& \mathrm{Wo}+\mathrm{CO}_{2}=\mathrm{Cc}+\mathrm{Qtz} \\
& \mathrm{Wo}+\mathrm{Scp}+\mathrm{Cc}=\mathrm{Grt}+\mathrm{CO}_{2} \\
& \mathrm{Wo}+\mathrm{Scp}=\mathrm{Grt}+\mathrm{Qtz}+\mathrm{CO}_{2} \\
& \mathrm{Wo}+\mathrm{Scp}=\mathrm{Grt}+\mathrm{An}+\mathrm{CO}_{2} \\
& \mathrm{Scp}+\mathrm{Qtz}=\mathrm{Grt}+\mathrm{An}+\mathrm{CO}_{2}
\end{aligned}
$$

MINERAL CHEMISTRY Chemical compositions of minerals were obtained using an Electron Probe Microanalyzer (JEOL JXA-8900 SuperProbe) in the Center for Microanalysis and Microscopy at the University of Maryland. For precise spot chemical analysis of mineral composition, operating conditions were 15 $\mathrm{kV}, 20 \mathrm{nA}$, with a 5-10 $\mu$ beam size. Natural materials were used as standards for all elements.

Calcite is the pure $\mathrm{Ca}$ end-member. Scapolite has Eq An (equivalent anorthite content) between 0.62 and 0.83 , with most grains with $0.66 ; ; \mathrm{Cl}$ and $\mathrm{SO}_{3}$ concentrations are very low, $<0.01 \%$ and $<0.02 \%$, respectively, which is typical of high-Ca scapolite. Garnet is
Ca rich, with a composition dominated by grossular $\left(\right.$ grs $_{98}$ and $\left._{2}\right)$. Feldspar occurs as ternary phase, with orthoclase $\left(\mathrm{or}_{95} \mathrm{ab}_{15}\right)$ as the host grain and exsolved plagioclase $\left(\mathrm{an}_{37}\right)$; the reintegrated composition is or ${ }_{74} \mathrm{ab}_{19} \mathrm{an}_{7}$. Clinopyroxene has $\mathrm{X}_{\mathrm{Mg}}$ around 0.70 and is zoned, with decrease of $\mathrm{Al}$ and increase of $\mathrm{Fe}$ from core to rim. Representative chemical compositions of all phases are given in table 1.

P-T CONDITIONS Clinopyroxene is the only Fe-Mg phase present in the rock, as garnet is almost pure grossular and all other phases are Ca-rich. Consequently, conventional thermobarometers cannot be used to calculate $P-T$ conditions. Therefore, $P-T$ conditions must be constrained from phase equilibria in the CASHC model system. We used the $T$ vs. $X_{\mathrm{CO} 2}$ projection drawn for $10 \mathrm{kbar}$ by Moecher \& Essene (1990). The presence of wollastonite with abundant calcite and wollastonite+scapolite is sufficient to infer $T>900$ $950^{\circ} \mathrm{C}$. The fluid present during metamorphism had 

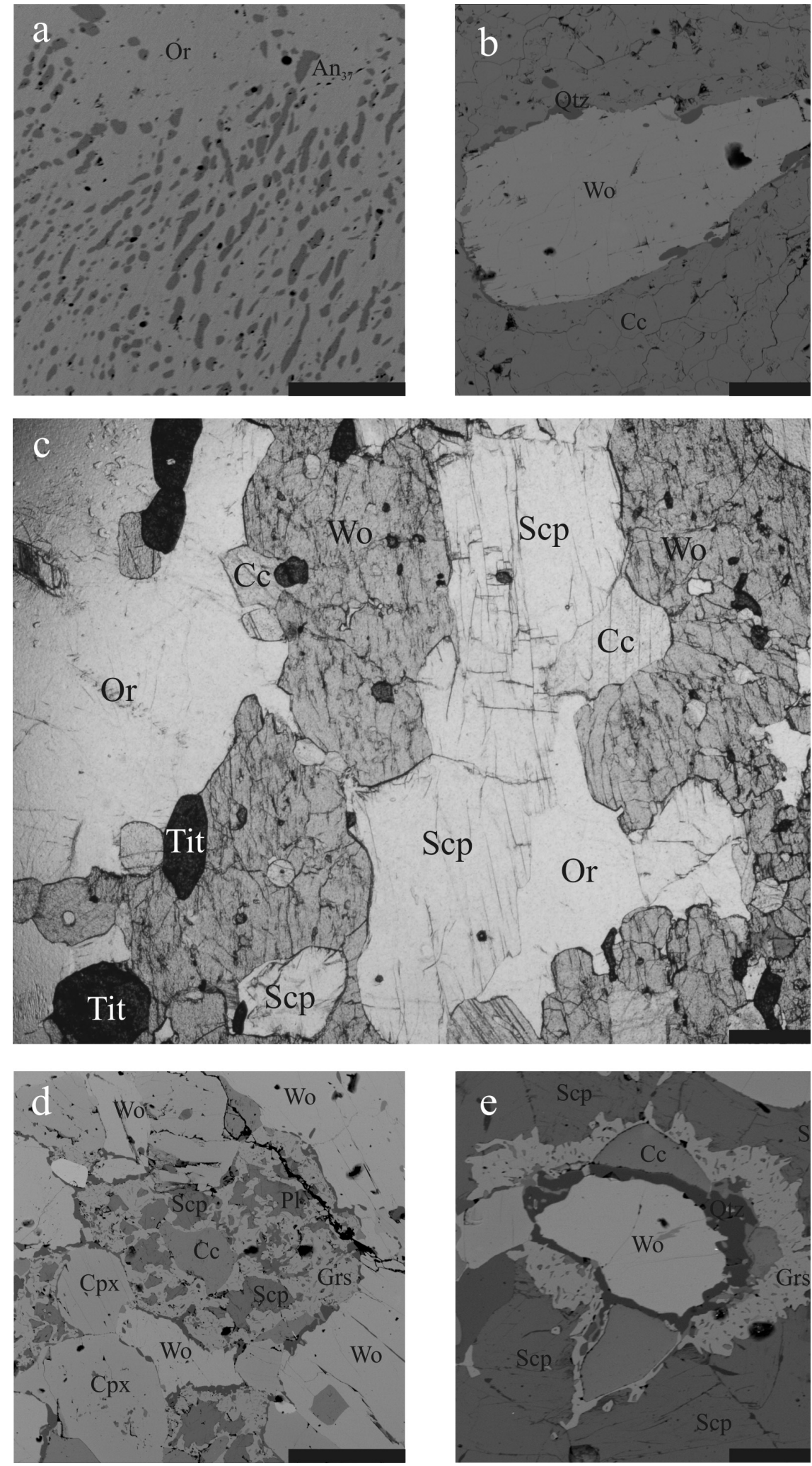

Figure 2 - Backscattered electron images and photomicrograph. (a) Ternary feldspar, with andesine (An37) exsolutions within orthoclase host. Scale bar is $0.7 \mathrm{~mm}$ long. (b) Wollastonite with a thin film of quartz and calcite. Scale bar is $0.7 \mathrm{~mm}$ long. (c) Wollastonite and scapolite in direct contact; titanite, ternary feldspar and calcite are also observed in the field of view. Plane polarized light; scale bar is $1.0 \mathrm{~mm}$ long. (d) Complex corona separating wollastonite from scapolite. Corona is composed of grossular+plagioclase with minor quartz and calcite. Scale bar is $0.7 \mathrm{~mm}$ long. (e) Composite corona composed of successive layers of quartz, calcite and grossular+plagioclase, separating wollastonite, in the center, from scapolite. Scale bar is $0.3 \mathrm{~mm}$ long. 
Table 1 - Representative chemical composition of main minerals determined by electron probe microanalyzer.

\begin{tabular}{|c|c|c|c|c|c|c|c|}
\hline Mineral & $\mathrm{Cpx}$ & $\mathrm{Cpx}$ & Wol & Grt & $\mathrm{Pl}$ & Or & Scp \\
\hline & core & rim & & & & & \\
\hline $\mathrm{SiO}_{2}$ & 51.65 & 51.93 & 50.87 & 40.13 & 59.16 & 64.66 & 45.62 \\
\hline $\mathrm{TiO}_{2}$ & 0.14 & 0.06 & 0.03 & 0.01 & - & - & - \\
\hline $\mathrm{Al}_{2} \mathrm{O}_{3}$ & 3.26 & 1.86 & 0.00 & 22.71 & 26.24 & 19.23 & 31.08 \\
\hline $\mathrm{Fe}_{2} \mathrm{O}_{3}$ & & & 0.47 & 0.76 & 0.04 & 0.00 & - \\
\hline $\mathrm{FeO}$ & 9.40 & 9.78 & 0.02 & 0.01 & 0.00 & 0.00 & - \\
\hline $\mathrm{MnO}$ & 0.14 & 0.16 & 0.11 & 0.06 & - & - & - \\
\hline $\mathrm{MgO}$ & 11.47 & 11.74 & 0.07 & 0.08 & - & - & - \\
\hline $\mathrm{CaO}$ & 24.14 & 24.67 & 48.27 & 37.71 & 7.07 & 0.03 & 20.01 \\
\hline $\mathrm{Na}_{2} \mathrm{O}$ & 0.13 & 0.06 & 0.00 & 0.00 & 7.40 & 1.03 & 1.61 \\
\hline $\mathrm{K}_{2} \mathrm{O}$ & 0.01 & 0.01 & 0.01 & 0.00 & 0.19 & 14.57 & 0.00 \\
\hline Totals & 100.33 & 100.25 & 99.84 & 101.50 & 100.10 & 99.54 & 98.32 \\
\hline oxygens & 6 & 6 & 6 & 12 & 8 & 8 & - \\
\hline $\mathrm{Si}$ & 1.933 & 1.950 & 1.979 & 2.974 & 2.635 & 2.979 & 6.832 \\
\hline $\mathrm{Ti}$ & 0.004 & 0.002 & 0.001 & 0.000 & - & - & - \\
\hline $\mathrm{Al}$ & 0.144 & 0.082 & 0.000 & 1.984 & 1.378 & 1.044 & 5.488 \\
\hline $\mathrm{Fe}^{3+}$ & 0.000 & 0.019 & 0.014 & 0.042 & 0.001 & 0.000 & - \\
\hline $\mathrm{Fe}^{2+}$ & 0.294 & 0.288 & 0.001 & 0.000 & 0.000 & 0.000 & - \\
\hline $\mathrm{Mn}$ & 0.004 & 0.005 & 0.004 & 0.004 & - & - & - \\
\hline $\mathrm{Mg}$ & 0.640 & 0.657 & 0.004 & 0.009 & - & - & - \\
\hline $\mathrm{Ca}$ & 0.968 & 0.992 & 2.012 & 2.998 & 0.337 & 0.002 & 3.212 \\
\hline $\mathrm{Na}$ & 0.009 & 0.004 & 0.000 & 0.000 & 0.639 & 0.092 & 0.468 \\
\hline $\mathrm{K}$ & 0.001 & 0.000 & 0.000 & 0.000 & 0.011 & 0.857 & 0.000 \\
\hline Sum & 3.99 & 4.000 & 4.014 & 8.012 & 5.001 & 4.974 & 16 \\
\hline $\mathrm{X}_{\mathrm{Mg}}$ & 0.69 & 0.70 & & & & & - \\
\hline An & & & & & 34.5 & & 82.93 \\
\hline
\end{tabular}

low $X_{\mathrm{CO} 2}$, but it was not pure $\mathrm{H}_{2} \mathrm{O}$ due to the lack of epidote-group minerals or any other hydrous phase in the rock. In domains where wollastonite occurs, it is surrounded by a thin corona of quartz+calcite, indicating that reaction 1 was crossed during cooling and/ or decompression and cooling. In the domains with wollastonite+scapolite, a corona of grossular-rich garnet+quartz+anorthite in the presence of calcite was most likely formed by crossing reactions 2 and 3, and as quartz started to be available, anorthite may have been formed by reactions 4 or 5 . These reactions form two possible paths. Crossing reactions 2 and 4 implies decreasing $X_{\mathrm{CO} 2}$ with almost no cooling, and crossing reactions 2,3 , and 5 implies cooling with a small decrease in $X_{\mathrm{CO} 2}$. We prefer the second interpretation, because it implies a similar $P-T$ path to those inferred for other portions of the Anápolis-Itauçu Complex (Moraes et al. 2002, Baldwin et al. 2005). A value of $X_{\mathrm{CO}}$ between 0.1 and 0.3 is inferred to be consistent with these reaction microstructures (Fig. 3).

The $T>900-950^{\circ} \mathrm{C}$ inferred from the

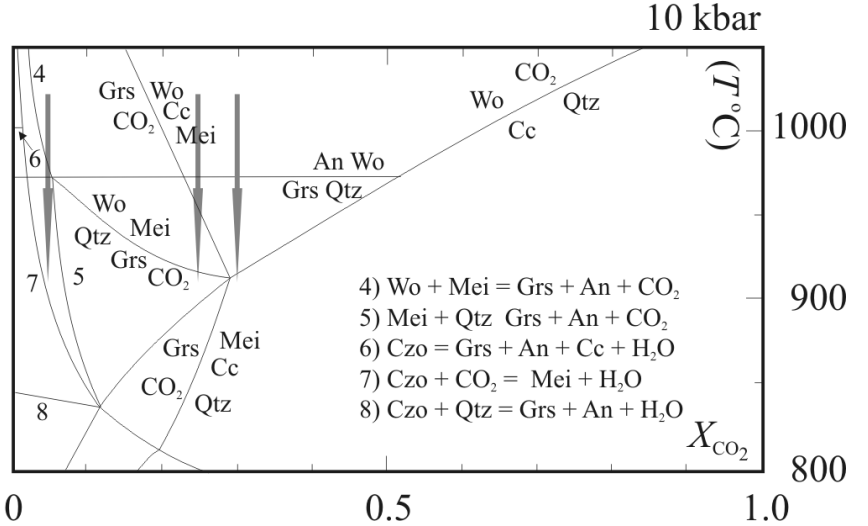

Figure $3-X_{\mathrm{CO}_{2}}$ vs. T diagram modified from Moecher \& Essene (1990). Wollastonite + scapolite in contact are only stable above $\sim 900{ }^{\circ} \mathrm{C}$ under low $X_{\mathrm{CO} 2}$ conditions.

mineral assemblages (mainly the coexistence of wollastonite+scapolite) might be overestimated, as the diagram was calculated for the CASHC system, and 
the scapolite composition is at the lower extreme of the meionite composition range, which will expand the scapolite stability field to lower $T$. However, this shift is not large, and the presence of ternary feldspar also suggests high $T$, around $1,000^{\circ} \mathrm{C}$.

GEOCHRONOLOGY Concentrates of titanite grains were separated for U-Pb dating. After crushing, titanite grains were separated using a conventional gravimetric (DENSITEST $\left.{ }^{\circledR}\right)$ technique and hand picking. For conventional TIMS U-Pb analysis, all fractions were dissolved in a concentrated solution of HF and $\mathrm{HNO}_{3}$ using microcapsules in Parr-type bombs. Solution was laid in a hot plate $\left(\mathrm{ca} .125-140^{\circ} \mathrm{C}\right)$ for three days. A mixed ${ }^{205} \mathrm{~Pb}^{2}{ }^{235} \mathrm{U}$ spike was used. Chemical extraction followed a standard anion exchange technique with Teflon microcolumns, following a modified routine set by Krogh (1973). U was collected with $\mathrm{HBr}$ following the procedure by Parrish et al. (1992). $\mathrm{Pb}$ and $\mathrm{U}$ were loaded onto a single $\mathrm{Re}$ filament with $\mathrm{H}_{3} \mathrm{PO}_{4}$ silica gel. Isotopic analysis was carried out at the Geochronology Laboratory of Universidade de Brasília, using a Finnigan MAT 262 multicollector mass spectrometer. Laboratorial blanch is better than $15 \mathrm{pg}$. Ages were calculated with PBDAT (Ludwig 1993) and ISOPLOT-Ex (Ludwig 2001). Results are presented in Table 2, and errors of isotopic ratios are given as $2 \sigma$.

$\mathrm{U}-\mathrm{Pb}$ in titanite yielded a date of $632 \pm 6 \mathrm{Ma}$ (Fig. 4). As titanite closure temperature for U-Pb system may be as high as $700^{\circ} \mathrm{C}$ (Frost et al. 2000), we in-

Table 2 - Titanite U-Pb isotopic data of Goianira marble.

\begin{tabular}{|c|c|c|c|}
\hline Sample/fraction & 2 & 3 & 4 \\
\hline Size (mg) & 0.142 & 0.148 & 0.178 \\
\hline U ppm & 69.9 & 62.9 & 77.6 \\
\hline $\mathrm{Pb}$ ppm & 8.1 & 6.9 & 19.2 \\
\hline $\mathrm{Pb}^{206} / \mathrm{Pb}^{204}$ & 664.28 & 927.26 & 62.66 \\
\hline $\mathrm{Pb}^{207 *} / \mathrm{Pb}^{235}$ & 0.875 & 0.855 & 0.811 \\
\hline (pct) & 1.25 & 0.92 & 0.77 \\
\hline $\mathrm{Pb}^{206^{*}} / \mathrm{U}^{238}$ & 0.103 & 0.102 & 0.099 \\
\hline (pct) & 0.94 & 0.89 & 0.43 \\
\hline Correl. Coefi. (rho) & 0.7575 & 0.9734 & 0.6191 \\
\hline $\mathrm{Pb}^{207 *} / \mathrm{Pb}^{206 *}$ & 0.061 & 0.0604 & 0.0588 \\
\hline (pct) & 0.82 & 0.21 & 0.61 \\
\hline $\mathrm{Pb}^{206^{*}} / \mathrm{U}^{238}$ Age & 635.6 & 629.7 & 613.8 \\
\hline $\mathrm{Pb}^{207} /{ }^{*} \mathrm{U}^{235}$ Age & 638.4 & 627.6 & 602.9 \\
\hline $\mathrm{Pb}^{207 / *} \mathrm{~Pb}^{206^{*}}$ Age & 648.1 & 620.0 & 562.1 \\
\hline$\pm(M a)$ & 18 & 4.6 & 13 \\
\hline Quant. & 5 & 8 & 9 \\
\hline
\end{tabular}

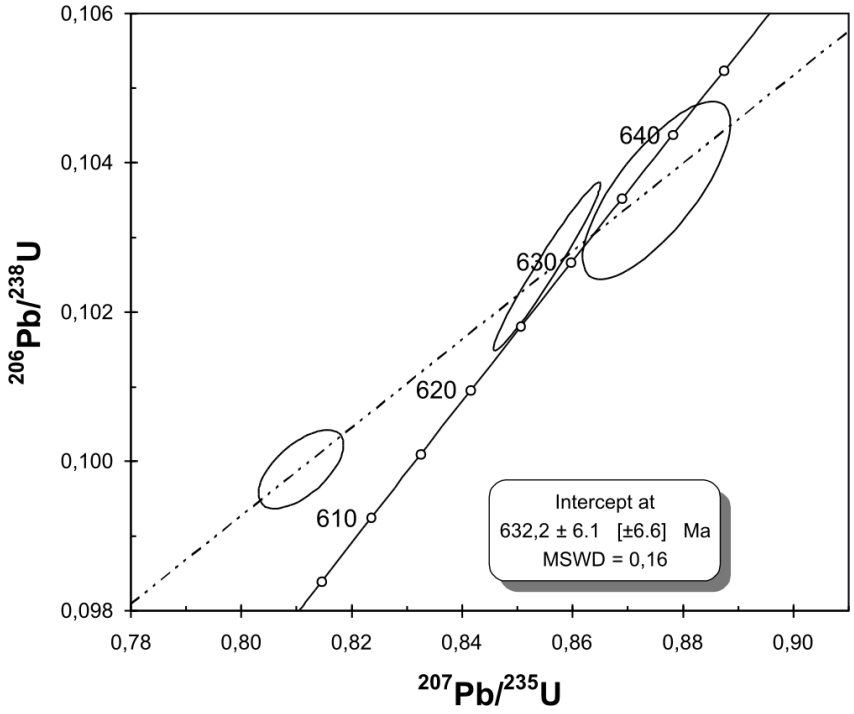

Figure 4 - Concordia diagram for ID-TIMS U Pb age for titanite from wollastonite-scapolite-clinopyroxene marble from Goianira.

terpret this age to record post-peak retrograde cooling and not the age of peak conditions during regional UHT metamorphism. However, we infer that peak metamorphic conditions probably were not much earlier than this age.

DISCUSSION The coexistence of stable wollastonite+scapolite and the presence of ternary feldspar confirm another occurrence of an ultrahigh-temperature mineral paragenesis in the Anápolis-Itauçu Complex, albeit in a different bulk composition than in $\mathrm{Al}-\mathrm{Mg}$ rich rocks. U-Pb dating has shown that some mafic rocks have crystallization ages between 6 to 34 Ma younger than the metamorphic peak in the Anápolis-Itauçu Complex (Laux et al. 2004, Hollanda et al. 2006). The impure marble described here is close to the Goianira-Trindade mafic-layered intrusion, but up to now, it has not been possible to determine the structural relationship between them. Zircon grains from a leucogabbro yielded a SIMS U-Pb age of $626 \pm 2 \mathrm{Ma}$, interpreted to record igneous crystallization (Hollanda et al. 2006). This age overlaps within uncertainty the TIMS U-Pb age of $632 \pm 6$ Ma obtained from titanite from the impure marble. Thus, we cannot rule out the possibility that contact metamorphism by the Goianira-Trindade mafic-layered intrusion was the heat source for UHT metamorphism, at least locally. However, it is more probable that asthenospheric heat was the source for the regional UHT metamorphism within the Anápolis-Itauçu Complex, and the basaltic magmatism more likely was the result of asthenosphere decompression as previously proposed (Moraes et al. 2002).

Acknowledgements This work is supported by FAPESP grant 04/09682-8 to R. M., FAPDF/Pronex 
grant 193.000.106/04 and CNPq grant 470183/04-7 to R.A.F., and NSF grant EAR-0227553 to M.B. The authors would like to acknowledge two anonymous referees for their reviews and suggestions.

\section{References}

Baldwin J.A., Powell R., Brown M., Moraes R. \& Fuck R.A. 2005. Modeling of mineral equilibria in ultrahigh-temperature metamorphic rocks from the Anápolis-Itauçu Complex, central Brazil. J. Metam. Geol., 23:511-531.

Brown M. \& Raith M. 1996. First evidence of ultrahigh-temperature decompression from the granulite province of southern India. J. Geol. Soc., 153:819-822.

Ferreira Filho C.F., Moraes R., Fawcett J.J. \& Naldrett A.J. 1998. Amphibolite to granulite progressive metamorphism in the Niquelândia Complex, Central Brazil: Regional Tectonic Implication. J. South Am. Earth Sci., 11: 35-50.

Frost B.R., Chamberlain K.R. \&, Schumacher J.C. 2000. Sphene-titanite: phase relations and role as a geochronometer. Chem. Geol., 172:131-148.

Fuck R.A., Pimentel M.M. \& Silva L.J.H.D. 1994. Compartimentação tectônica da porção oriental da Província Tocantins. In: SBG, Cong. Bras. Geol, 38, Balneário Camboriú, Anais, v.1, p. 215-216.

Harley S.L. 1998. On the occurrence and characterization of ultrahigh-temperature crustal metamorphism. In: P.J. Treloar \& P.J. O'Brien (eds.) What Drives Metamorphism and Metamorphic Reactions? Geol. Soc. London, Special Publication, v.138, p. 81-107.

Harley S.L. \& Hensen B.J. 1990. Archaean and Proterozoic high-grade terranes of East Antarctica $\left(40-80^{\circ} \mathrm{E}\right)$ : a case study of diversity in granulite facies metamorphism. In: J.R. Ashworth \& M. Brown (eds.) High Temperature Metamorphism and Crustal Anatexis. Unwin Hyman, London, p. 320-370.

Hollanda M.H.B.M., Pimentel M.M., Armstrong R. \& Nilson A.A. 2006. Syn- to late-Brasiliano mafic magmatism and crustal re-melting in the southern Brasília Belt. J. S. Am. Earth Sci. (submitted).

Kretz R. 1983. Symbols for rock-forming minerals. Am. Mineral., 68:277-279.

Krogh T.E. 1973. A low-contamination method for hydrotermal decomposition of zircon and extraction of $\mathrm{U}$ and $\mathrm{Pb}$ for isotopic age determinations. Geoch. Cosmoch. Acta, 37:485-494.

Lacerda Filho J.V., Marques V., Szislewiski G., Jorge L., Justo E.C. \& Oliveira C.C. 1991. Projeto Geologia da Região Centro-Oeste, Folha Caraiba, CPRM, Goiânia, 145 p.

Laux J.H., Pimentel M.M., Dantas E.L., Armstrong R., Armele A. \& Nilson A.A. 2004. Mafic magmatism associated with the Goiás magmatic arc in the Anicuns region, Goiás, central Brazil: Sm-Nd isotopes and new ID-TIMS and SHIMP U-Pb data. J. South Am. Earth Sci., 16:599-614.

Leite C.M.M. 2002. A Evolução Geodinâmica da Orogênese Paleoproterozóica nas regiões de Capim Grosso-Jacobina e Pintadas-Mundo Novo (Bahia-Brasil): Metamorfismo, Anatexia e Tectônica. Tese de Doutorado, Instituto de Geociências, Universidade Federal da Bahia, 411 p.
Ludwig K.R. 1993. PBDAT. A computer program for processing $\mathrm{Pb}$-U-Th isotope data. USGS Open File Report 88$542,34 \mathrm{p}$.

Ludwig K.R. 2001. Users Manual for Isoplot/Ex version 2.47. A geochronological toolkit for Microsoft Excel. Berkeley Geochronology Center Special Publication 1a, 55 p.

Moecher D.P. \& Essene E.J. 1990. Phase equilibria for calcic scapolite and implications of variable Al-Si disorder for $P-T, T-\mathrm{X}_{\mathrm{CO} 2}$ and $a-X$ relations. J. Petrol., 31:997-1024.

Moraes R. \& Fuck R.A. 2000. Ultra High Temperature Metamorphism in Central Brazil: The Barro Alto Complex. $J$. Metam. Geol., 18:345-358.

Moraes R., Brown M., Fuck R.A., Camargo M.A. \& Lima T.M. 2002. Characterization and $P-T$ evolution of meltbearing ultrahigh-temperature granulites: an example from the Anápolis-Itauçu Complex of the Brasília Fold Belt, Brazil. J. Petrol., 43:1673-1705.

Moraes R., Campos Neto M.C. \& Fuck R.A. 2006. Novas ocorrências de granulitos com espinélio+quartzo em Goiás. In: SBG, Cong. Bras. Geo., 43, Aracaju, Anais, p. 190.

Nilson A.A. 1984. O atual estágio de conhecimento dos complexos máfico-ultramáficos pré-cambrianos do Brasil uma avaliação preliminar. In: SBG, Cong. Bras. Geo., 33, Rio de Janeiro, Anais, p. 4166-4203.

Oliveria M.A.F. \& Alves F.R. 1976. Wollastonita em associações cálcicas de facies granulito. Rev.Bras.Geoc., 6:13-19

Parrish R.R., Bellerive D. \& Sullivan R.W. 1992. U-Pb chemical procedures for titanite and allanite in the Geochronology Laboratory, Geological Survey of Canada. Geol. Surv. Canadian Paper, 91(2):187-190.

Pimentel M.M., Fuck R.A., Jost H., Ferreira Filho C.F. \& Araújo S.M. 2000. The basement of the Brasília Fold Belt and the Goiás Magmatic Arc. In: U.G. Cordani, E.J. Milani, A. Thomaz Filho \& D.A. Campos (eds.) Tectonic Evolution of South America. Rio de Janeiro, Brazil, p. 195-229.

Pimentel M.M., Jost H. \& Fuck R.A. 2004. O Embasamento da Faixa Brasília e o Arco Magmático de Goiás. In: V. Mantesso-Neto, A. Bartorelli, C. Dal Ré Carneiro \& B.B. Brito Neves (orgs.) Geologia do Continente Sul-Americano: Evolução da Obra de Fernando Flávio Marques de Almeida. 1 ed., São Paulo, Beca, p. 355-368.

Piuzana D., Pimentel M.M., Fuck R.A. \& Armstrong R. 2003. Neoproterozoic granulite facies metamorphism and coeval granitic magmatism in the Brasília Belt, central Brazil: regional implications of SHRIMP U-Pb and Sm-Nd data. Precambrian Res., 125:245-273.

Stormer Jr.J.C. 1973. The composition of sapphirine from Salvador, Bahia, and conditions of its formation. Rev. Bras. Geoc., 3:192-200. 